\title{
Did Andreas Vesalius's De Humani Corporis Fabrica and/or Juan Valverde's Historia De La Composicion Del Cuerpo Humano Really Influence the Anatomy Knowledge in the Ottoman Empire? A Preliminary Study on Shams al-Dīn 'Itāqī's Tashrīh al-Abdān ${ }^{*}$
}

\author{
Ahmet Acıduman**- Çağatay Aşkit**- Gözde Acıduman ${ }^{* * * * *}$
}

\begin{abstract}
Aim of this study was to determine whether Vesalius and Valverde influenced Shams al-Dīn 'Itāqī considering the figures and several statements in Tashrịh al-Abdān wa Tarjamān Qỉbāla Faylasūfān. The statements and figures in illustrated copies of 'Itāqī's book were examined and compared to those in Galen's, Avicenna's, Vesalius's, and Valverde's works, then the findings were evaluated. 'Itāqī's book contains some figures only from Vesalius and/or Valverde's works, but there is no new explanation related to issues such as the mandible, the sacrum, the rete mirabile, and the uterus. The Latin edition of Valverde's book published in 1607 was probably the source of the Western-originated illustrations in the manuscript Hüsrev Paşa, Nr. 464 and of all the Western-based illustrations, except for the female figure in the manuscript of Istanbul University, Turkish Manuscripts, TY 2662. Spanish and/or Italian and/or Latin (1589) editions of Valverde's book were the sources of most of the Western-originated illustrations, except the human skeleton figure in the manuscript of Prof. Uzluk's personal collection. The information given by the works of Vesalius and Valverde
\end{abstract}

* This article is based on an oral presentation at the $44^{\text {th }}$ Congress of the International Society for the History of Medicine "The Great Silk Road \& Medicine", held in Tbilisi, Georgia, September $10^{\text {th }}-14^{\text {th }}, 2014$. DOI: $10.37879 /$ belleten. 2021.545

** Prof., Department of History of Medicine and Ethics, Faculty of Medicine, Ankara University, Ankara/TURKEY, aciduman@medicine.ankara.edu.tr ORCID: 0000-0003-2021-4471

**** Assoc. Prof., Department of Ancient Languages and Cultures, Sub-Department of Latin Language and Literature, Faculty of Languages, History and Geography, Ankara University, Ankara/TURKEY, cagatayaskit@yahoo.com ORCID: 0000-0001-6357-320X

***** M.D., Department of Public Health, Faculty of Medicine, Hacettepe University, Ankara/ TURKEY, acidumangozde@gmail.com ORCID: 0000-0003-2980-1138 Application date of article: 28.08.2020 - Approval date of article: 05.04.2021 
has not influenced the explanations of 'Itāqī. 'Itāqī wrote his book according to the classical anatomical knowledge in the Islamic world of his era and he added Easternand Western-originated figures to his book to support/strengthen his statements. Or 'Itāqī work Tasrịh al-Abdān originally contained no illustrations. However, later, scribes/copiers added Eastern- and Western-originated anatomical figures to the book to support/strengthen statements at different times.

Keywords: Shams al-Dīn 'Itāqī, Tashrīh al-Abdān wa Tarjamān Qỉbāla Faylasūfān, Andreas Vesalius, Juan Valverde, Anatomy, History of medicine.

\section{Andreas Vesalius'un De Humani Corporis Fabrica's1 ve/veya Juan Valverde'nin Historia De La Composicion Del Cuerpo Humano'su Osmanlı İmparatorluğu'nda Anatomi Bilgisini Gerçekten Etkiledi mi? Şemsü'd- dīn 'İtāḳ̄’nin Teşriḥül-Ebdān'ı Üzerine Bir Ön Çalışma}

\section{Öz}

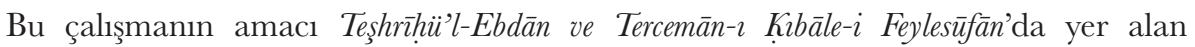
şekilleri ve bazı açıklamaları göz önüne alarak Vesalius ve Valverde'nin Şemsü'd-dīn 'İtāḳ̂̀ yi etkileyip etkilemediğini belirlemektir. 'İtāḳìnin kitabının resimli nüshalarının açıklamaları ve şekilleri incelenmiş ve Galenus'un, İbn Sina'nın, Vesalius'un ve Valverde'nin eserleriyle karşılaştırılmış, sonra bulgular değerlendirilmiştir. 'İtāḳ̂̀nin kitabı Vesalius ve/veya Valverde'nin eserlerinden yalnızca bazı şekilleri içermekte, fakat mandibula, sakrum, rete mirabile ve uterus gibi konularda yeni bir açıklama bulunmamaktadır. Valverde'nin 1607 tarihinde yayımlanmış Latince baskısı, Hüsrev Paşa, Nr. 464 yazmasındaki ve kadın figürü dışında, İstanbul Üniversitesi, Türkçe Yazmalar, TY 2662 yazmasındaki bütün Batı kaynaklı şekillerin olası kaynağıdır. Valverde’nin kitabının İspanyolca ve/veya İtalyanca ve/veya Latince (1589) baskıları Prof. Uzluk'un kişisel koleksiyonundaki yazmada yer alan, insan iskeleti şekli dişında, pek çok Batı kaynaklı çizimlerin kaynağıdır. Vesalius ve Valverde'nin eserlerinde verilen bilgiler 'İtāḳ̂̀nin açıklamalarını etkilememiştir. 'İtāḳi kitabını kendi dönemindeki İslam dünyasının klasik anatomi bilgisine göre yazmış ve açıklamalarını desteklemek/ güçlendirmek için kitabına Doğu ve Batı kaynaklı şekiller eklemiştir ya da 'İtāḳ̂̀’nin eseri başlangıçta çizimler içermemekle birlikte, daha sonra, istinsah edenler Doğu ve Batı kaynaklı anatomik şekilleri açıklamaları desteklemek/güçlendirmek için değişik zamanlarda kitaba ilave etmişlerdir.

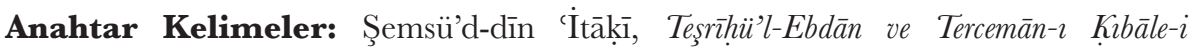
Feylesūfān, Andreas Vesalius, Juan Valverde, Anatomi, Tip tarihi. 


\section{Introduction}

Bìmāristāns and madrassas were establishments where medical education was done in Islamic countries during medieval times. Either a section was opened in a madrassa or a separate madrassa was built for medical education. Based on this tradition, the Turks also established foundations for medical education. Physicians were educated in bìmāristans/dār al-shifās and madrassas during the Seljukid and Ottoman Era ${ }^{1}$.

Nidhāmī Arūệ̄'s Chahār Maqāla contained valuable information regarding the sources of medical education in the Seljuk Empire during the $12^{\text {th }}$ century $\mathrm{AD}^{2}$. It also classified the medical works for students, from beginner to advanced. Here is an interesting statement related to Avicenna's Canon of Medicine: "If he [the physician] desires to be independent of other works, he may content himself with the Qánún."." As a matter of fact, the Canon of Medicine was one of the main sources of medical education both in the Eastern and the Western world ${ }^{4}$, and it was also a source of inspiration for medical works written after ${ }^{5}$.

During the Turkish history of Anatolia, particular attention was paid to the study of anatomy which was regarded as the sine qua non for medical education. Şehsuvaroğlu, a well-known Turkish historian of medicine, classified the history of the study of anatomy into four phases in his article related to the study of anatomy in Turkey. He named the first phase the "madrassa period," which was between the years 1205 and 1816 AD. The Canon of Medicine written in Arabic was the main source used for medical education during this period ${ }^{6}$. However, there

1 Ali Haydar Bayat, Tip Tarihi, 1. Baskı, Sade Matbaa, İzmir 2003, pp. 177, 231, 268, 272.

2 Nidhámí-i-'Arúdí-i-Samarqandí, The Chahár Maqála ("Four Discourses"), Translated into English by Edward G. Browne, [Reprinted from the Journal of the Royal Asiatic Society, July and October, 1899], Luzac \& Co., London 1900.

3 Nidhámí-i-'Arúḍ́-i-Samarqandí, ibid., p. 110.

4 Bayat, ibid., p. 190.

5 F. Nafiz Uzluk, "İbni Sina Eşşeyhürreis”, Büyük Türk Filozof ve Tıb Üstade İbni Sina: Şahsiyeti ve Eserleri Hakknda Tetkikler", Türk Tarih Kurumu Yaynnları, Muallim Ahmet Halit Kitap Evi, İstanbul 1937, p. 2; Aslan Terzioğlu, “İbn Sīnā’nın Tabābeti ve Avrupa'ya Tesirleri”, Aydın Sayılı (ed.), İbn Sînâ Doğumunun Bininci Yil Armağam, T.C. Atatürk Kültür, Dil ve Tarih Yüksek Kurumu, Türk Tarih Kurumu Yayınları, Ankara 1984, pp. 52-53; Esin Kâhya, "İbn Sînâ’nın Anatomisinin Osmanlı Hekimleri Üzerindeki Etkisi”, Bilim Tarihi, 15 (1993), pp. 3-6; Esin Kâhya, "One of the Samples of the Influences of Avicenna on the Ottoman Medicine, Shams al-Din Itaqi", Belleten, LXIV/239 (2000), pp. 63-68.

6 Bedi N. Şehsüvaroğlu, "Bizde Anatomi Öğretimine Dair," İstanbul Üniversitesi Trp Fakültesi Mecmuast, XV/1 (1952), pp. 365-367. 
also emerged some Turkish medical books with anatomy sections ${ }^{7}$ and also books written solely on anatomy ${ }^{8}$. The Tashrīh al-Abdān wa Tarjamān Qibāla Faylasūfān, an illustrated anatomy book written by Shams al-Dīn 'Itāqī, was one of the latter'.

\section{Shams al-Dīn 'Itāqī and Tashrīḥ al-Abdān wa Tarjamān Qibāla Faylasüfän}

Shams al-Dīn 'Itāqī was born in Shirwan (c. 1570 AD). He studied medicine, mathematics, logic, astronomy, canonical jurisprudence of Islam, and Hadith for twenty years ${ }^{10}$. He was also a poet and 'Itāqī was his pen name ${ }^{11}$. He left his country because of conflicts and stayed abroad for a while, after which he came to İstanbul ${ }^{12}$, where Alī Efendi and İbrāhīm Efendi introduced him to Grand Vizier Receb Pasha. He was assigned to Mecca city as Shaikh al-Kharam. While in his sixties, he wrote an anatomy book in Turkish, called Tashrịh al-Abdān wa Tarcamān Qibāla Faylasūfān, and dedicated it to the Ottoman Sultan Murad IV (r. 1623-1640 $\mathrm{AD})^{13}$.

Kâhya reported that the book was probably written in $1632^{14}$. There are eight known copies of Tashrịh al-Abdān and four of them comprise anatomical illustrations which are one of the most important features of the work ${ }^{15}$. Some of these

7 Ḩayrü'd-Dīn ibn Elhāc Bāyezīd bin 'Ömer Şāh, Kìtābu Hulāsati’t-Ţıbb, AÜTF Deontoloji AD Kütüphanesi, Nr. 15402/a, 1088/[1677-8], pp. 8-16; Ahmet Acıduman ve Önder İlgili, "Hekim Hayreddin'in "Hulâsatü't-Tıbb" Adlı Eserinde "Tıbbi Deontoloji” ve "Nöroanatomi" ile ilgili Bölümler", Sinir Sistemi Cerrahisi Derg, II/1 (2009), p. 46; Abdülvehhâb bin Yûsuf ibn-i Ahmed el-Mârdânî, Kitâbu'l-Müntehab fìt-Tıb (823/1420), İnceleme-Metin-Dizin-SadeleştirmeTıpkıbasım. Hazırlayan: Ali Haydar Bayat, Merkezefendi Geleneksel Tıp Derneği, İstanbul 2005, pp. 52-72, 362-378; Hekim Bereket, Tuhfe-i Mübāriz̄, Metin-Sözlük, Hazırlayan: Binnur Erdağı Doğuer, Türk Dil Kurumu Yayınları, Ankara 2013, pp. 33-49.

8 A. Süheyl [Ünver], "Üç̧ Asırlık Resimli Bir Teşrih Kitabımız "Risalei Tarihi Ebdan” Şirvanlı Şemsettin (Itakî) 1622-1648", Tedavi Notlan IX/7 (1934), pp. 189-193; Şehsuvaroğlu, ibid., 367368; Esin Kahya, "Şemseddin-i İtaki'nin Anatomi Kitabı", Araştırma, VIII (1970), pp. 171-186.

9 Esin Kâhya, Şemseddîn-i İtâkînnin Resimli Anatomi Kitabı, Atatürk Kültür, Dil ve Tarih Yüksek Kurumu, Atatürk Kültür Merkezi, Ankara 1996.

10 Esin Kâhya, Şemseddîn-i İtâkînin Resimli Anatomi Kitabı, p. 1.

11 [Ünver], ibid., p. 189.

12 [Ünver], ibid., p. 190.

13 [Ünver], ibid., p. 190; Kâhya, Şemseddîn-i İtâkînin Resimli Anatomi Kïtabı, p. 2.

14 Kâhya, Şemseddîn-i İtâkînin Resimli Anatomi Kitabı, p. 3.

15 Kâhya, Şemseddîn-i İtâkînin Resimli Anatomi Kitabı, pp. 2-6; Ekmeleddin İhsanoğlu (ed,), Osmanlı Trbbi Bilimler Literatürü Tarihi (History of the Literature of Medical Sciences During the Ottoman Period), 1. Cilt, Hazırlayanlar: Ekmeleddin İhsanoğlu, Ramazan Şeşen, M. Serdar Bekar, Gülcan Gündüz, Veysel Bulut, İslam Konferansı Teşkilatı, İslam Tarih, Sanat, Kültür Araştırma Merkezi (IRCI- 
illustrations look like those of Tashrĭh al-Abdān min al-Tibb written by Manșūr b. Muhammad b. Ahmad (Figure 1) ${ }^{16}$, while others were copied from Andreas Vesalius's De humani corporis fabrica ${ }^{17}$ and/or Juan Valverde de Amusco's Historia de la composicion del cuerpo humano ${ }^{18}$. Kâhya stated that the last set of illustrations was drawn by the author himself (Figure 2$)^{19}$.

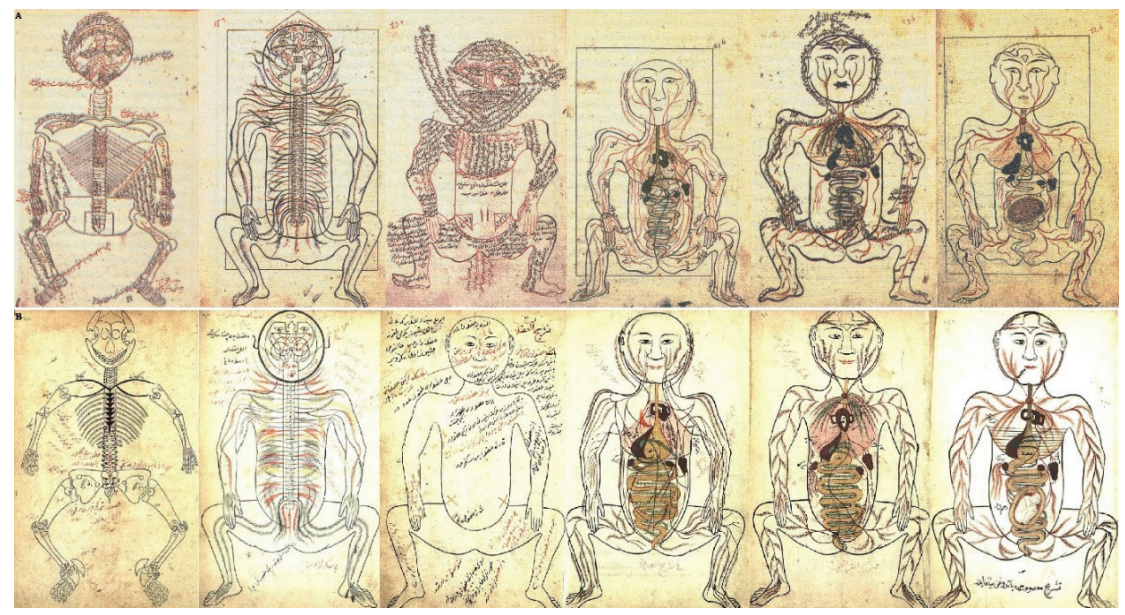

Figure 1. Comparison of the similar figures in Manșūr b. Muhammad b. Aḥmad's Tashrīh al-Abdān min al-Tỉbb (A) and Shams al-Dīn 'Itāqī’s Tashrīh al-Abdān wa Tarjamān Qibāla Faylasūfān (Courtesy of Türkiye Yazma Eserler Kurumu Başkanlığı, İstanbul, Turkey) (B).

CA), İstanbul 2008; pp. 304.

16 Gül Russell, "The Owl and the Pussy Cat" the Process of Cultural Transmission in Anatomical Illustration", Ekmeleddin İhsanoğlu (ed). Transfer of modern Science \& Technology to the Muslim World. Proceedings of the International Symposium On "Modern Sciences and the Muslim World". Science and Technology Transfer From the West to the Muslim World From the Renaissance to the Beginning of the XXth Century (Istanbul 2-4 September 1987). The Research Centre for Islamic History, Art and Culture (IRCICA), İstanbul 1992, p. 191; Kâhya, Şemseddîn-i İtâkînin Resimli Anatomi Kitabr, p. 7; Miri Shefer-Mossenshon, Ottoman Medicine: Healing and Medical Institutions, 1500-1700. State University of New York Press, Albany 2009, pp. 48-49; İlhan Bahşi and Ayşe Bahşi, "Teşrih-ül Ebdan ve Tercümânı Kıbale-i Feylesûfan": the First Illustrated Anatomy Handwritten Textbook in Ottoman-Turkish Medicine", Surgical and Radiologic Anatomy, XLI/ 10 (2019), p. 1142.

17 Russell, ibid., p. 191; Kâhya, Şemseddîn-i İtâkînin Resimli Anatomi Kitabı, p. 7; Shefer-Mossenshon, ibid., p. 49; Dániel Margócsy, Márk Somos, Stephen N. Joffe, "Vesalius' Fabrica: A Report on the Worldwide Census of the 1543 and 1555 Editions, Soc Hist Med, XXX (2017), pp. 203; Bahşi and Bahşi, ibid., p. 1142.

18 Russell, ibid., p. 191; Shefer-Mossenshon, ibid., p. 49; Bahşi and Bahşi, ibid., p. 1142.

19 Kâhya, Şemseddîn-i İtâkînin Resimli Anatomi Kitabı, p. 7. 
Another feature of the work is that Shams al-Dīn 'Itāqī wrote it purely on anatomy, which was rare in the Medieval Islamic world and in the Ottoman Empire. Anatomy was usually considered a section in general medical works ${ }^{20}$.

The last feature of the work was that it was written in Turkish, and consequently, it contained anatomical terms in Turkish alongside the Arabic and Persian ones ${ }^{21}$. This makes Tashrịh al-Abdān important to the history of Turkish medicine, considering the fact that Arabic was the scientific language of the Medieval Islamic world.

The main purpose of our study was to determine whether Andreas Vesalius and Juan Valverde de Amusco, together with their works, influenced Shams al-Dīn 'Itāqī considering the figures and several statements in Tashrīh al-Abdān wa Tarjamān Qibāla Faylasūfān.

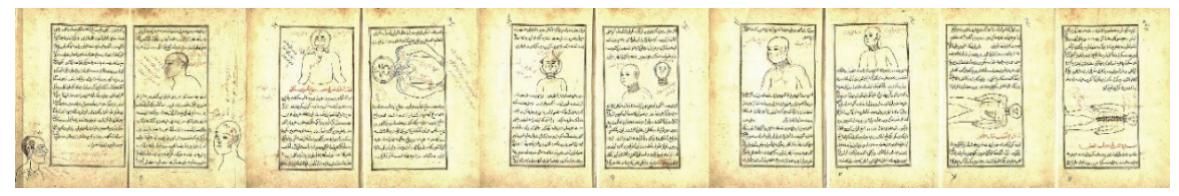

Figure 2. Some of the figures that are claimed to have been drawn by Shams al-Dìn 'Itāqī in Tashrīh al-Abdān wa Tarjamān Qibāla Faylasūfān (Courtesy of Türkiye Yazma Eserler Kurumu Başkanlığı, İstanbul, Turkey).

\section{Material and Method}

In this study, four illustrated copies of Tashrīh al-Abdān wa Tarjamān Qỉbāla Faylasüfān of Shams al-Dīn 'Itāqī were examined among them were copies of the İstanbul Süleymaniye Manuscript Library, Hüsrev Paşa Collection, Nr. 464 used regarding both their content and the figure ${ }^{22}$ they contain originating from the West. Besides, the copy of İstanbul University Rare Works Library, Turkish Manuscripts, TY $2662^{23}$ and the black \& white photo prints, which are in the Library of History

Kâhya, Şemseddîn-i İtâkînin Resimli Anatomi Kitabı, pp. 6-7.

21 [Ünver], ibid., p. 193; Şehsüvaroğlu, ibid., 367; Kâhya, Şemseddîn-i İtâkînin Resimli Anatomi Kitabı, p. 6.

22 Shams al-Dīn 'Itāqī, Tashrīh al-Abdān wa Tarjamān Qỉbāla Faylasūfān, Türkiye Yazma Eserler Kurumu Başkanlığı, İstanbul Süleymaniye Manuscript Library, Hüsrev Paşa Collection, Nr. 464, ff. 1v, 30r, 31r, 32r, 41r, 44r, 46v, 47r-v, 48v, 49r-v, 50r-v, 51r-v, 52v, 60r, 73v, 74r, 84v, 108r, 118r, $122 \mathrm{v}, 123 \mathrm{r}$.

23 Shams al-Dīn 'Itāqī, Tashrịh al-Abdān wa Tarjamān Qỉbāla Faylasūfān, İstanbul University Rare 
of Medicine Department, Faculty of Medicine, Ankara University, of the copy of Prof. Uzluk's personal collection ${ }^{24}$ were also analyzed with respect to their figures originating from the West (Figure 3). The copy of the İstanbul Süleymaniye Manuscript Library, Bağdatlı Vehbi Collection, Nr. 1476 was excluded from the study due to its shortage in these figures. During this study, Galen's works ${ }^{25}$, alQānūn fì al-Tíbb of Avicenna ${ }^{26}$, De humani corporis fabrica of Andreas Vesalius ${ }^{27}$, and Historia de la composicion del cuerpo humano of Juan Valverde de Amusco ${ }^{28}$ with its Italian $^{29}$ and Latin editions ${ }^{30}$, were also used. The statements and figures in Tashrĭh al-Abdān wa Tarjamān Qibāla Faylasüfän were compared to those in Galen's works, al-Qānūn fì al-Tibb, De humani corporis fabrica and Historia de la composicion del cuerpo humano and the findings were evaluated.

Works Library, Turkish Manuscripts, TY 2662, ff. 1v, 16r, 19r-v, 23r, 25v, 60v, 66r, 69r.

24 Shams al-Dīn 'Itāqī, Tashrīh al-Abdān wa Tarjamān Qỉbāla Faylasūfān, Ankara University, Institute of History of Medicine (B\&W Photo prints).

25 Galen, On the Natural Faculties, with An English Translation by Arthur John Brock, William Heinemann, London, Putnam's Sons, New York 1916; Charles Singer, "Galen's Elementary Course on Bones", Proceedings of the Royal Society of Medicine XXXXV/11, pp. 767-776; Galen, On the Usefulness of the Parts of the Body, De Usu Partium, Translated from the Greek with an Introduction and Commentary by Margaret Tallmadge May, I-II, Cornell University Press, Ithaca, New York 1968.

26 Abū 'Alī Ibn Sīnā, Al-Qānūn fì al-Tỉibb, Vol. II, al-Maṭba'at al-Āmira, [Būlāq] 1294/[1877]; Mazhar H. Shah, The General Principles of Avicenna's Canon of Medicine, Naveed Clinic, Karachi, Pakistan 1966; Avicenna (Abū 'Alī al-Husayn ibn 'Abd Allāh ibn Sīnā), The Canon of Medicine (al-Q̄ānūn fì'l-tibb), Adapted by Laleh Bakhtiar from Translations of Volume I by O. Cameron Gruner and Mazar H. Shah Correlated with the Arabic by Jay R. Crook with Notes by O. Cameron Gruner. Series Editor Sayyed Hossein Nasr. Great Books of the Islamic World, Inc. 1999.

27 Andreas Vesalius, De Hvmani corporis fabrica libri septem. Per Ioannem Oporinum, Basileae 1555; J. B. deC. M. Saunders and Charles D. O'Malley (eds.), The Illustrations from the Works of Andreas Vesalius of Brussels, With Annotations and Translations, A Discussion of the Plates and Their Background, Authorship and Influence, and A Biographical Sketch of Vesalius by J. B. deC. M. Saunders and Charles D. O'Malley. Second Printing. The World Publishing Company, Cleveland and New York 1950.

28 Ioan de Valuerde, Historia de la composcion del cuerpo humano, Impressa por Antonio Salamanca, y Antonio Lafrerij, En Roma 1556.

29 Giouan Valverde, Anatomia del corpo humano \& da luy con molte figure di rame, et eruditi discorsi in luce mandata, In Roma Per Ant. Salamanca, et Antonio Lafrerj, 1559.

30 Ioanne Valverdo, Anatome corporis humani, Nunc primum a Michaele Columbo latine reddita, et additis nouis aliquot tabulis exornata, Studio et industria Ivntarvm, Venetiis 1589; Ioanne Valverdo, Anatome corporis humani, Nunc primum a Michaele Colúbo latine reddita, et additis nouis aliquot tabulis exornata, Studio et industria Ivntarvm, Venetiis 1607. 


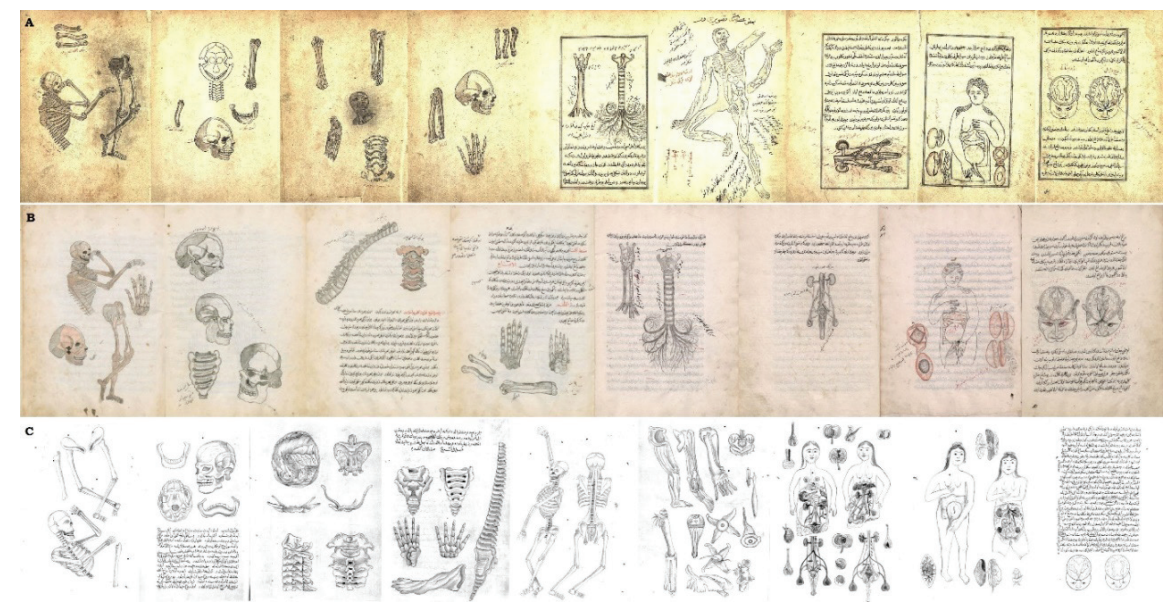

Figure 3. Figures originating from the West in copies of Tashrīh al-Abdān wa Tarjamān Qibāla Faylasū ān in the İstanbul Süleymaniye Manuscript Library, Hüsrev Paşa Collection, Nr. 464 (Courtesy of Türkiye Yazma Eserler Kurumu Başkanlığı, İstanbul, Turkey) (A), İstanbul University Turkish Manuscripts, TY 2662 (Courtesy of İstanbul University Rare Works Library, İstanbul, Turkey) (B) and Prof. Uzluk's personal collection (Courtesy of Department of History of Medicine and Ethics, Faculty of Medicine, Ankara University, Ankara, Turkey) (C).

\section{Results}

\section{The Mandible}

We see that although Shams al-Dīn 'Itāqī copied the figure of the mandible from Andreas Vesalius and/or Juan Valverde, in explaining this figure he repeated classical anatomical knowledge inherited from Galen ${ }^{31}$ and Avicenna ${ }^{32}$, by indicating that the mandible consists of two bones ${ }^{33}$. One of the earliest objections to Galen's authority is seen in Abd al-Lațîf al-Baghdādī’s (1162-1231 AD) Kitāb al-Ifāda wa l-Itiba $\bar{r}$ in which he wrote that the mandible is a single bone ${ }^{34}$. Andreas Vesali-

31 Singer, ibid., p. 771.

32 Avicenna, ibid., p. 62.

33 Shams al-Dīn 'Itāqī, Tashrīh al-Abdān, Hüsrev Paşa Collection 464, f. 25v; Al-Itāqī, The Treatise on Anatomy of Human Body and Interpretation of Philosophers, Esin Kahya (ed), National Hijra Council, Islamabad 1410/1990, p. 44.

34 George Sarton, Introduction to the History of Science, Volume II, from Rabbi Ben Ezra to Roger Bacon, in Two Parts, Part II, Reprinted, Published for the Carnegie Institution of Washington 
us also objected to Galen similarly in De humani corporis fabrica libri septem ${ }^{35}$. Juan Valverde's description of the mandible ${ }^{36}$ corresponds to that of contemporary anatomical knowledge (Table 1) (Figure 4) ${ }^{37}$.

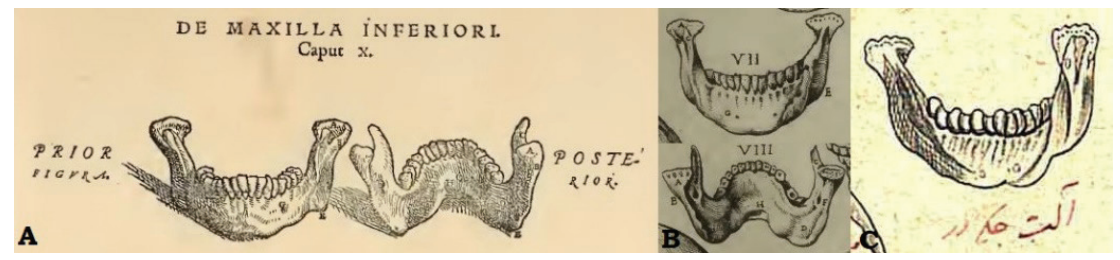

Figure 4. Figures showing the mandible from Vesalius's De humani corporis fabrica (A), Valverde's Anatomia del corpo humano (B) and 'Itāqī’s Tashrīh al-Abdān, Hüsrev Paşa, Nr. 464

(Courtesy of Türkiye Yazma Eserler Kurumu Başkanlığı, İstanbul, Turkey) (G).

\section{The Sacrum}

'Itāqī repeated the classical knowledge ${ }^{38}$ inherited from Galen ${ }^{39}$ and Avicenna ${ }^{40}$ regarding the number of vertebrae in the sacrum as three. While Vesalius gave the number of vertebrae in the sacrum as $\operatorname{six}^{41}$, Valverde considered it as six, and sometimes five ${ }^{42}$. 'Abd al-Lațif al-Baghdādī wrote that the sacrum [al-'ajz] with the coccyx $\left[a l^{-} a j b\right]$ consists generally of a single bone, instead of six in his Kitāb al-Ifāda wa l-Itibār (Table 2) (Figure 5) ${ }^{43}$.

by the Williams and Wilkins Company, Baltimore 1962, p. 599; 'Abd al-Latịf al-Baghdādī, Rihlat

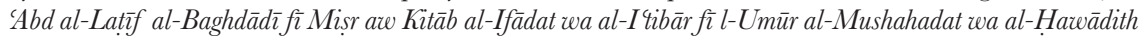
al-Mu'âyanat bi-Ard Mișr. Țab'at al-Thāniya [The Second Edition]. Al-Shaikh AA (ed). Hay'at al-Mișriyyat al-'Amat li-l-Kitāb 1998, pp. 149-150; Rabie E. Abdel-Halim, "Experimental medicine 1000 years ago", Urology Annals, III/2 (2011), p. 59.

35 Vesalius, ibid., p. 54.

36 Valverde, Anatomia del corpo humano, f. 8r.

37 Peter L. Williams and Mary Dyson (eds.), Gray's Anatomy, Thirty-Seventh Edition, ELBS Edition First Published 1992, Reprinted, ELBS with Churchill Livingstone, Edinburgh 1992, pp. 367, 369.

38 Shams al-Dīn 'Itāqī, Tashrīh al-Abdān, Hüsrev Paşa Collection 464, f. 29r; Al-'Itāqī, ibid., p. 47.

39 Singer, ibid., p. 772.

40 Avicenna, ibid., p. 70.

41 Vesalius, ibid., p. 100.

42 Valverde, Anatomia del corpo humano, f. 12r.

43 Sarton, ibid., p. 599; 'Abd al-Lațîf al-Baghdādī, ibid., p. 150. 


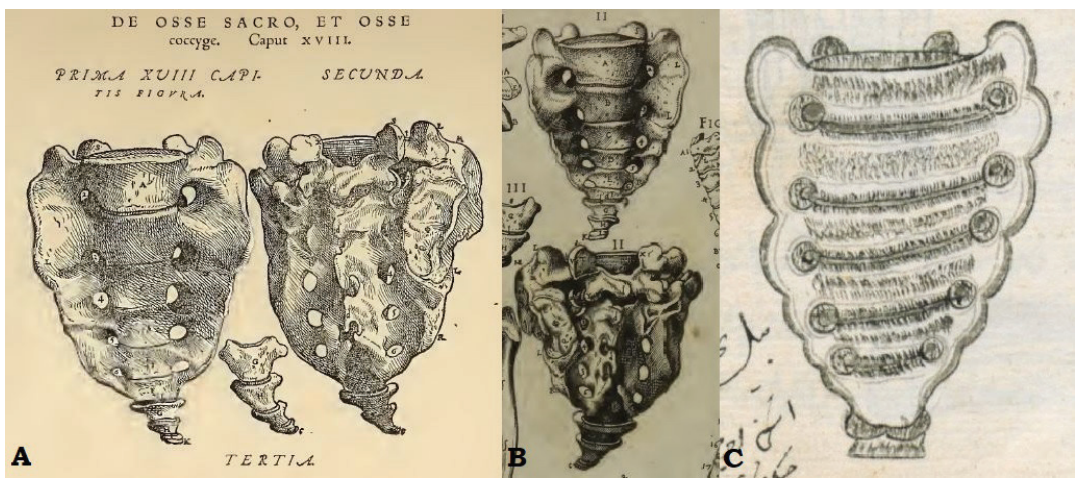

Figure 5. Figures showing the sacrum and coccyx from Vesalius's De humani corporis fabrica (A), Valverde's Anatomia del corpo humano (B) and 'Itāqī’s Tashrīh al-Abdān, İstanbul University Turkish Manuscripts, TY 2662 (Courtesy of İstanbul University Rare Works Library, İstanbul, Turkey) (G).

Leonardo da Vinci was the first anatomist who gave the correct number, five ${ }^{44}$. Saunders and Malley's comment on the illustration of the sacral bone, which consists of six vertebrae in De humani corporis fabrica, is really interesting:

"Jacobus Sylvius, Vesalius' teacher in Paris, insisted that the Galenical texts were completely correct with regard to number, hence Vesalius, in order to some extent to accommodate Galen's opinion, grudgingly allowed that by adding the three sacral to the three coccygeal segments of the ape, and assuming that the rest of the coccyx or caudal vertebrae were not ossified, he could harmonize opinion. This was one of the reasons that he selected a six-piece sacrum for the illustration below ${ }^{45}$."

This statement corresponds to 'Abd al-Laṭif Baghdādī's acceptance of six fused vertebrae [probably three for the sacrum and three for the coccyx] as a single bone, but not clear enough regarding the coccyx.

\section{The Coccyx}

'Itāqī description of the coccyx ${ }^{46}$ was the same as Galen's ${ }^{47}$ and Avicenna's ${ }^{48}$. Ve-

44 Charles D. O’Malley and J. B. de C. M. Saunders (eds), Leonardo da Vinci on the Human Body: the Anatomical, Physiological, and Embryological Drawings of Leonardo da Vinci. Henry Schuman [1952], p. 42.

45 Saunders and O’Malley (eds.), ibid., p. 66.

46 Shams al-Dīn 'Itāqī, Tashrīh al-Abdān, Hüsrev Paşa Collection 464, f. 29v; Al-'Itāqī, ibid., p. 48.

47 Singer, ibid., p. 773.

48 Avicenna, ibid., p. 71. 
salius gave the correct number ${ }^{49}$ and Valverde affirmed this number but also wrote a variation comprising three bones (Table 3$)^{50}$. Leonardo da Vinci declared it to be two bones ${ }^{51}$.

\section{The Metacarpus \& the Phalanges of the Hand}

'Itāqī follows ${ }^{52}$ Galen $^{53}$ and Avicenna ${ }^{54}$ in his description of the number of metacarpal and finger bones. Although Vesalius ${ }^{55}$ and Valverde ${ }^{56}$ made some explanations about whether the number of metacarpal bones is four or five, they also admitted that the metacarpus has four bones, and every finger of the hand consists of three bones. According to modern anatomical knowledge, the number of metacarpal bones is five and the total number of finger bones of the hand is fourteen; two in each thumb, and three in each of the other fingers (Table 4) $(\text { Figure 6) })^{57}$.

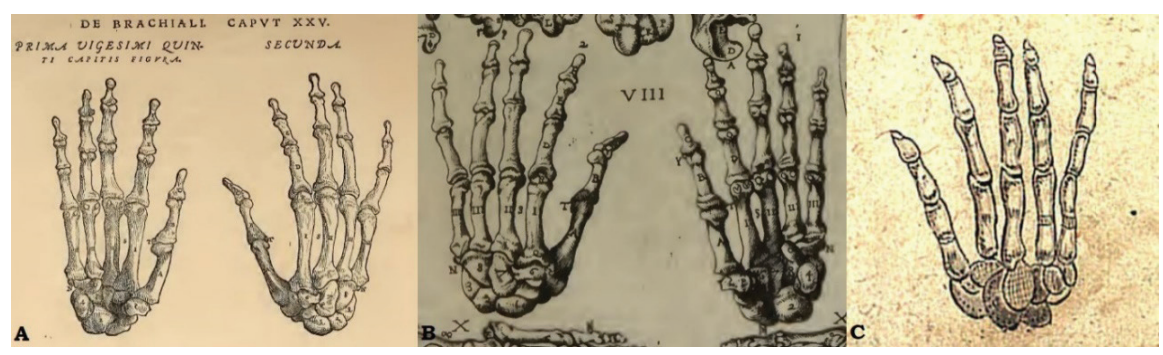

Figure 6. Figures showing the metacarpus and the phalanges of the hand from Vesalius's De humani corporis fabrica (A), Valverde's Anatomia del corpo humano (B) and 'Itāqī's Tashrịh al-Abdān, Hüsrev Paşa, Nr. 464 (Courtesy of Türkiye Yazma Eserler Kurumu Başkanlığı, İstanbul, Turkey) (C).

\section{The Metatarsus \& the Phalanges of the Foot}

Regarding the number of the metatarsal bones and the bones of the toes, there

49 Vesalius, ibid., p. 100.

50 Valverde, Anatomia del corpo humano, f. $12 \mathrm{v}$.

51 O'Malley and Saunders (eds.), ibid., p. 42.

52 Shams al-Dīn 'Itāqī, Tashrīh al-Abdān, Hüsrev Paşa Collection 464, f. 35r-v; Al-'Itāqīi, ibid., p. 51.

53 Singer, ibid., p. 774.

54 Avicenna, ibid., pp. 77-78.

55 Vesalius, ibid., pp. 146, 149.

56 Valverde, Anatomia del corpo humano, ff. 18v, 19r.

57 Williams and Dyson (eds.), ibid, pp. 418, 420. 
is no difference between the information given by Galen ${ }^{58}$, Avicenna ${ }^{59}$, Vesalius ${ }^{60}$, Valverde $^{61}$, 'Itāq1 ${ }^{-62}$, and modern anatomical knowledge (Table 5) (Figure 7) ${ }^{63}$.

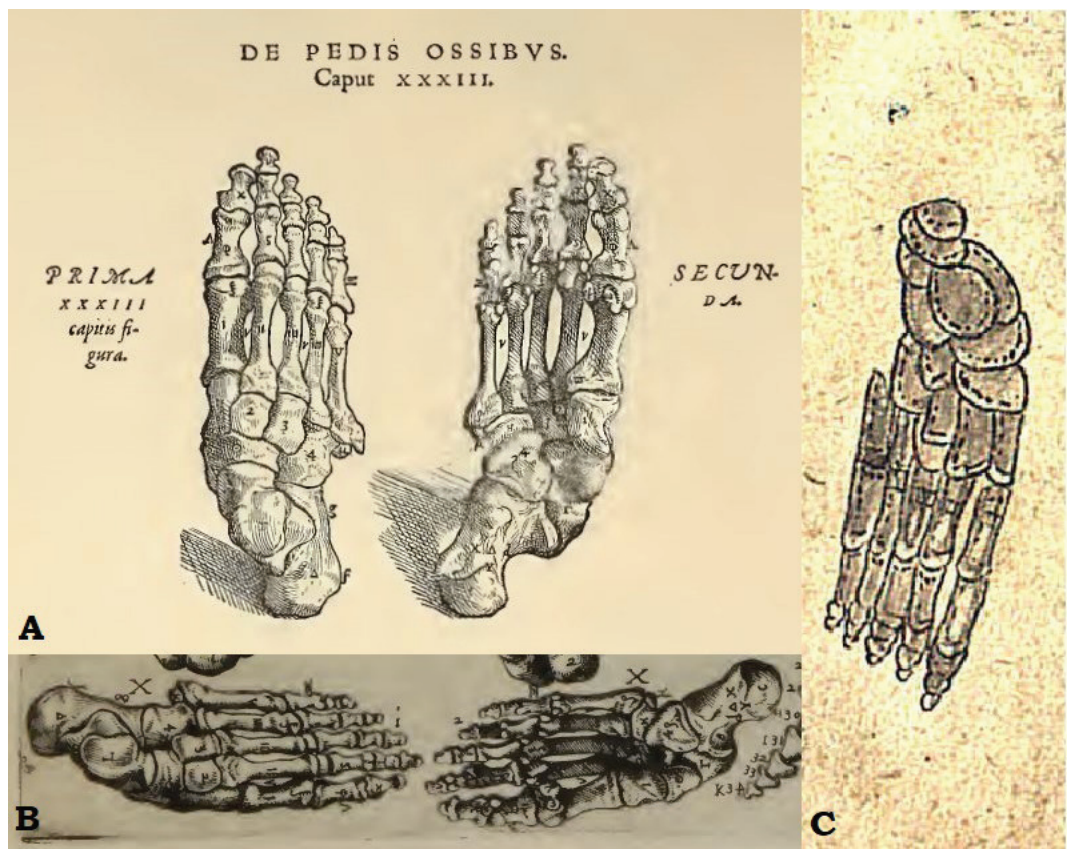

Figure 7. Figures showing the metatarsus and the phalanges of the foot from Vesalius's

De humani corporis fabrica (A), Valverde's Anatomia del corpo humano (B) and 'Itāqī’s Tashrīh al-Abdān, Hüsrev Paşa, Nr. 464 (Courtesy of Türkiye Yazma Eserler Kurumu Başkanlığı, İstanbul, Turkey) (C).

\section{The Optic Nerve, the Optic Ghiasma, \& the Oculomotor Nerve}

'Itāqī may have tried to support his explanations on the optic nerves, the optic chiasma, and the oculomotor nerves with the figures copied from Vesalius and/or Valverde. However, these figures actually show the cerebral fornix and lateral ventricles. The

\footnotetext{
58 Singer, ibid., p. 775.

59 Avicenna, ibid., p. 82.

60 Vesalius, ibid., pp. 180-181.

61 Valverde, Anatomia del corpo humano, f. 25r.

62 Shams al-Dīn 'Itāqī, Tashrīh al-Abdān, Hüsrev Paşa Collection 464, ff. 38v, 39r; Al-'Itāqī, ibid., p. 53.

63 Williams and Dyson (eds.), ibid, pp. 454-455.
} 
optic nerves, the optic chiasm, and the oculomotor nerves appear at the base of the brain, and Vesalius's and Valverde's works contain figures depicting them. But it seems that 'Itāqī did not understand the structures correctly as seen in the figures (Figure 8 and 9).

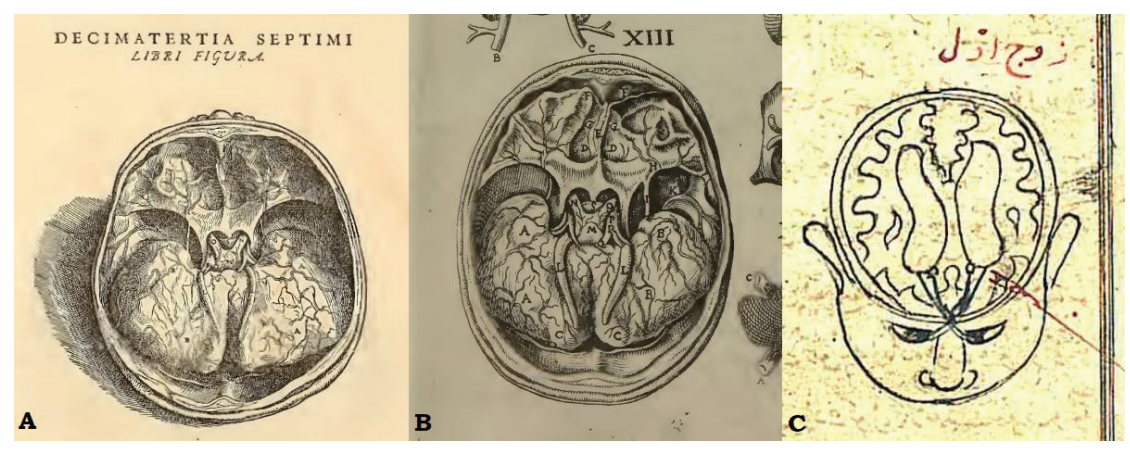

Figure 8. Figures showing the optic nerve and the optic chiasma from Vesalius's $D e$ humani corporis fabrica (A), Valverde's Anatomia del corpo humano (B) and 'Itāqī's Tashrīh alAbdān, Hüsrev Paşa, Nr. 464 (Courtesy of Türkiye Yazma Eserler Kurumu Başkanlığı, İstanbul, Turkey) (C).
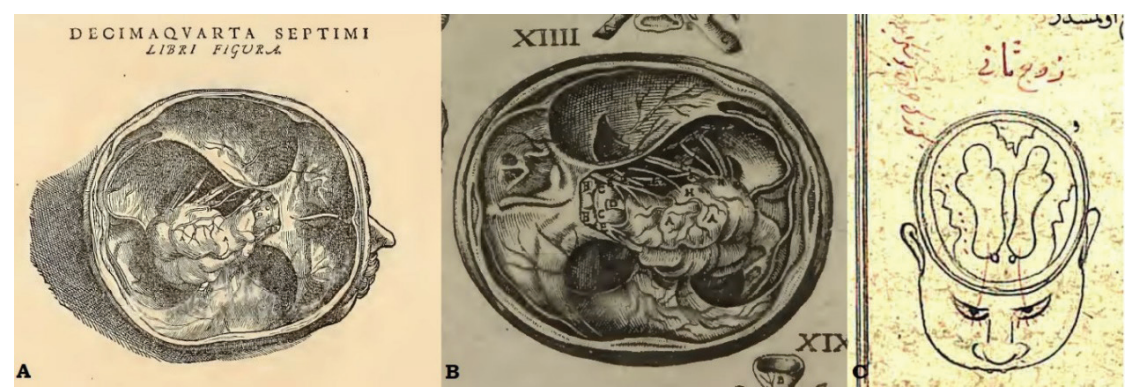

Figure 9. Figures showing the oculomotor nerve from Vesalius's De humani corporis fabrica (A), Valverde's Anatomia del corpo humano (B) and 'Itāqī's Tashrīh al-Abdān, Hüsrev Paşa, Nr. 464 (Courtesy of Türkiye Yazma Eserler Kurumu Başkanlığı, İstanbul, Turkey) (C).

\section{The Rete Mirabile}

Andreas Vesalius ${ }^{64}$ and Juan Valverde ${ }^{65}$ declared that the rete mirabile or the reticular

64 Vesalius, ibid., p. 796.

65 Valverde, Anatomia del corpo humano, ff. 117r, 131v. 
plexus, whose existence was accepted and mentioned by Galen ${ }^{66}$ and Avicenna, was absent in human beings. Unfortunately, 'Itāqì's book does not contain this important finding, though it contains a chapter explaining the rete mirabile/shabaka dimägh (Table 6) ${ }^{67}$.

\section{The Uterus}

Vesalius said that though the fundus of the female uterus is bestowed with a single sinus $^{68}$, Galen assigned two sinuses to his uterus, as he often described it as his $D e$ usu partium $^{69}$. Valverde also asserted that there are not many chambers in the uterus as some believed or found ${ }^{70}$. However, 'Itāqī repeats the information ${ }^{71}$ given by Galen and Avicenna ${ }^{72}$ (Table 7).

\section{Discussion}

This preliminary study reveals that 'Itāqī reflected classical anatomical knowledge in the Islamic world of his era and Avicenna's Canon of Medicine was the main source of his statements in the text. 'Itāqī's book contains some figures only from Vesalius and/or Valverde's works, but there is no new explanation related to issues such as the mandible, the sacrum, the rete mirabile, and the uterus.

On the other hand, 'Itāqī seems to be unaware of 'Abd al-Lațîf al-Baghdādì's work disclosing the mandible and the sacrum [with coccyx] as single bones. Although he put an explanation on the anatomy of the heart [the heart has two cavities] from Ibn al-Nafis's (d. 1288 AD) Sharh al-Tashrịh al-Qānūn, 'Itāqī preferred to give the classical anatomical knowledge on the heart [the heart has three cavities $]^{73}$ mentioned in the Canon of Medicine ${ }^{74}$. Also, considering that Ibn al-Nafis says there is no passage that appears in the interventricular septum of the heart or

Galen, On the Usefulness of the Parts of the Body, pp. 430-431.

Vesalius, ibid., p. 666.

Galen, On the Usefulness of the Parts of the Body, p. 625.

Valverde, Anatomia del corpo humano, f. 90r.

Ibn Sīnā, ibid., p. 556. 105.

Ibn Sīnā, ibid., p. 261.

Shams al-Dīn 'Itāqī, Tashrīh al-Abdān, Hüsrev Paşa Collection 464, ff. 89v-90r; Al-'Itāqī, ibid., p. 89.

Shams al-Dīn 'Itāqī, Tashrīh al-Abdān, Hüsrev Paşa Collection 464, f. 12 lv; Al-Itāqī, ibid., p. 116.

Shams al-Dīn 'Itāqī, Tashrīh al-Abdān, Hüsrev Paşa Collection 464, ff. 108v-109r-v; Al-'Itāqī, ibid., p. 
there is no invisible passage as Galen thought ${ }^{75}$ and Vesalius also gives very similar statements ${ }^{76}$, 'Itāqī's explanations referring to Ibn al-Nafīs seem to be not in accordance with the statements of Ibn al-Nafis, but are compatible with those of Galen $^{77}$. And as Adivar noted ${ }^{78}$, 'Itāqī's quotation from Ibn al-Nafis disclosed that he unfortunately did not understand Ibn al-Nafis' statements on the pulmonary circulation (Table 8).

\section{Who is 'Itāq'ī's source for his figures? Andreas Vesalius or Juan Valverde?}

Many of the figures that originated from the West in 'Itāqī's Tashrịh al-Abdān wa Tarjamān Qibāla Faylasüfän also appear in Vesalius's De humani corporis fabrica libri septem and in Juan Valverde's Historia de la composicion del cuerpo humano. The similarities between the figures of Vesalius and of Valverde caused Juan Valverde de Amusco to be accused of plagiarism. However, the figures in Valverde's Historia are reverse versions of the ones in Vesalius's book and this is an expected result when someone copies a figure on a plate and then prints it. When Western-originated figures in 'Itāqì's book are compared with those in both De humani corporis fabrica and Historia de la composicion del cuerpo humano, it is seen that most of them are very similar to those of Vesalius's De humani corporis fabrica, except for the cervical vertebral figure and female figure which correspond to Tab. V. del Lib. I and Tab. VI. del Lib. III in Valverde's book. On the other hand, the figure of the man displaying body muscles among the figures of 'Itāqi appears only in the Latin edition of Valverde's work (Figure 10). This fact made us raise this question: Which one of these works did Shams al-Dīn 'Itāqī see? Or did Shams al-Dīn 'Itāqī see both of them?

75 Max Meyerhof, "Ibn An-Nafis (XIIIth cent.) and His Theory of the Lesser Circulation", Isis, XXIII/1 (1935), p. 117; Sami I. Haddad, Amin A. Khairallah, "A Forgotten Chapter in the History of the Circulation of the Blood", Annals of Surgery, CIV/1 (1936), p. 5; Manfred Ullmann, Islamic Medicine, Edinburgh University Press, Edinburgh 1978, pp. 68-69.

76 Galen, On the Usefulness of the Parts of the Body, n. 87, pp. 323-324.

77 Galen, On the Natural Faculties, p. 321.

78 A. Adnan Adivar, Osmanl Türklerinde İlim, 6. Basım. Remzi Kitabevi, İstanbul 2000, pp. 129-130. 


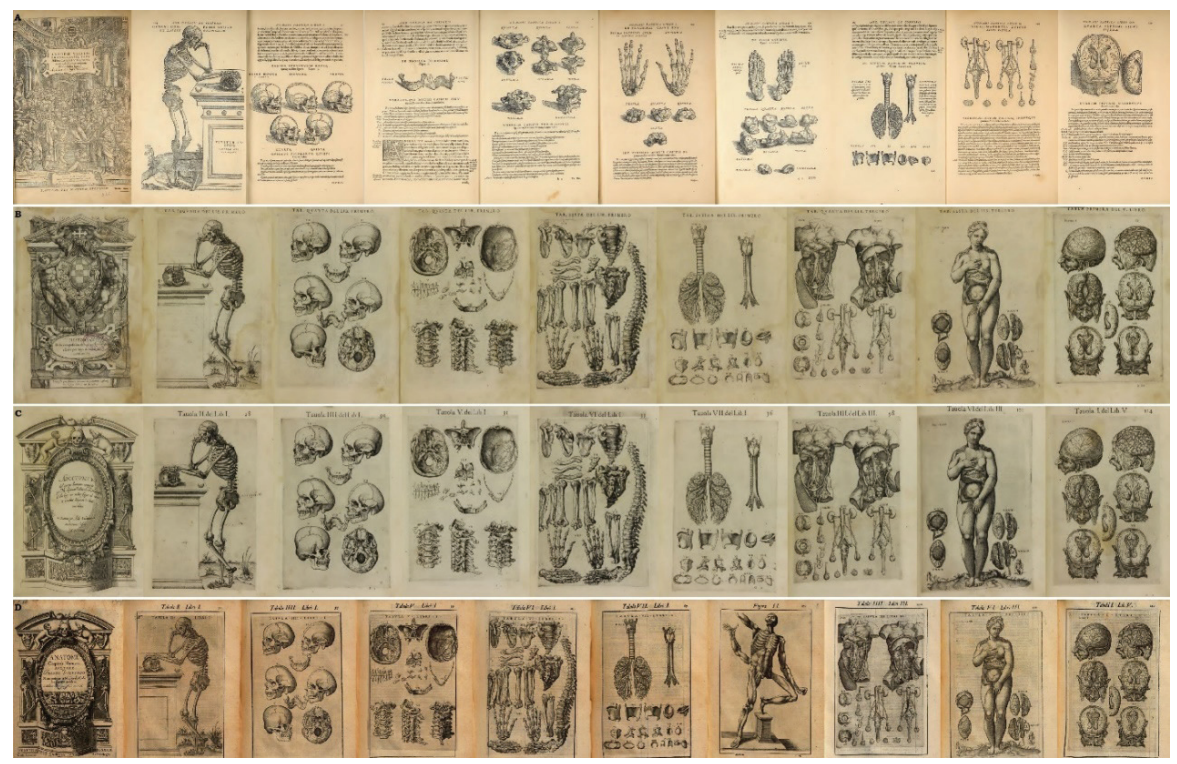

Figure 10. The figure pages in Vesalius's De humani corporis fabrica libri septem (1555) (A), Juan Valverde's Historia de la composicion del cuerpo humano (1556) (B), and its Italian (1559) (C) and Latin (1589) (D) editions that are related to the figures originating from the West in 'Itāqī's Tashrīh al-Abdān wa Tarjamān Qỉbāla Faylasūfān.

All figures, including the figure depicting seven cervical vertebrae, the figure showing body muscles, and the female figure together reveal that the Western-originated figures in 'Itāqī's book are probably related to Valverde's book of Latin edition in 1589. However, this assumption raises another question. The problem is that all the figures in the manuscript Hüsrev Paşa, Nr. 464 are in a reverse position to those in Valverde's book in Latin edition (1589) and in this respect, most of them correspond to those in Vesalius's book except for the three figures mentioned above. If someone draws a figure looking at any object, he/she should draw what he/she sees! In this case, it comes to mind that there should be a copy of Valverde's work that answers all these questions. Our comparisons between the figures of all editions of Vesalius's and Valverde's works have made it clear that the Latin edition of Valverde's book Anatome Corporis Humani published in 1607 was the source of the Western-originated illustrations in the manuscript Hüsrev Paşa, Nr. 464 (Figure 11). 


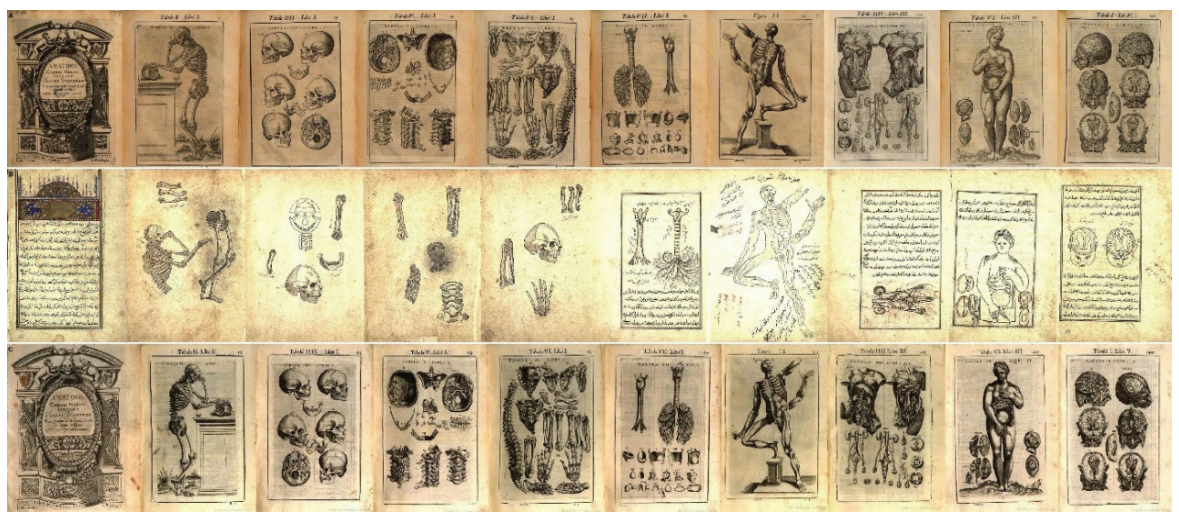

Figure 11. 1589 (A) and 1607 (C) Latin editions of Juan Valverde's work entitled Anatome Corporis Humani and Hüsrev Paşa Collection, Nr. 464 copy of 'Itāqī’s Tashrīh al-Abdān (Courtesy of Türkiye Yazma Eserler Kurumu Başkanlığı, İstanbul, Turkey) (B).

However, while the figures depicting the human skeleton, spine, and cervical vertebrae in the manuscript of Istanbul University, Turkish Manuscripts, TY 2662 are corresponding to those in Hüsrev Paşa, Nr. 464, the female figure in the manuscript of Istanbul University, Turkish Manuscripts, TY 2662 seems to be drawn opposite to that in Hüsrev Paşa, Nr. 464. As such, how do we explain these pictures?

The Latin edition of Valverde's book Anatome Corporis Humani published in 1607 probably was the source of all the Western-based illustrations, except for the female figure in the manuscript of Istanbul University, Turkish Manuscripts, TY 2662. This figure was probably copied from any of the Spanish, Italian, or Latin (1589) editions of Valverde's book (Figure 12). 


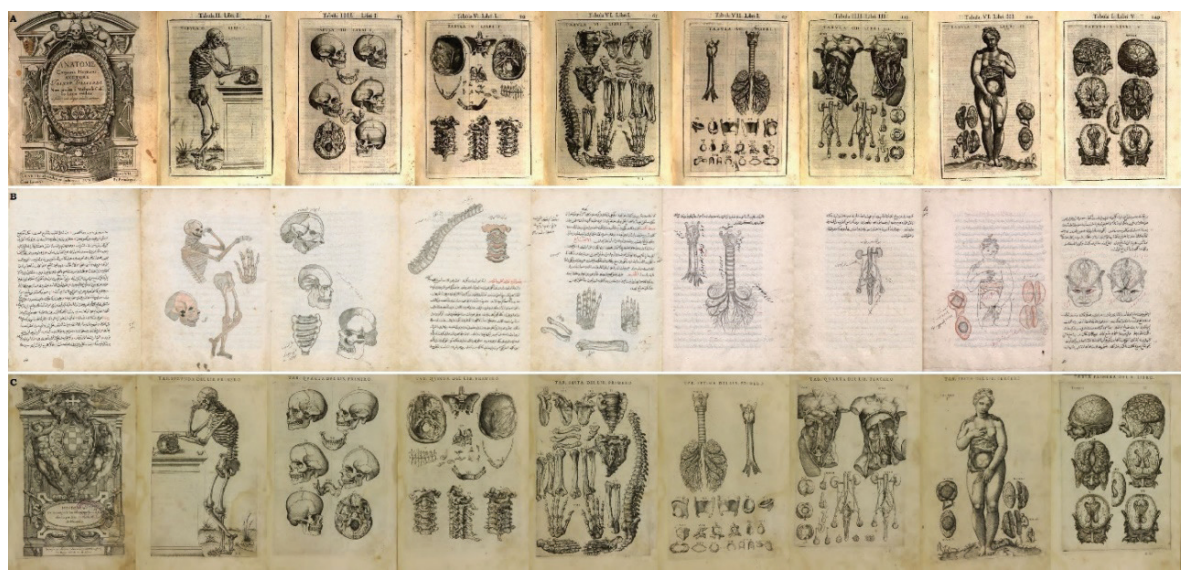

Figure 12. 1607 (A) Latin edition of Juan Valverde's work entitled Anatome Corporis Humani, its Spanish (C) edition (1556) entitled Historia de la composicion del cuerpo humano and İstanbul University Turkish Manuscripts, TY 2662 copy (Courtesy of İstanbul University Rare Works Library, İstanbul, Turkey) (B) of 'Itāqī's Tashrīh al-Abdān.

Spanish and/or Italian and/or Latin (1589) editions of Valverde's book were the sources of most of the Western-originated illustrations, except the human skeleton figure in the manuscript of Prof. Uzluk's personal collection (Figure 13).

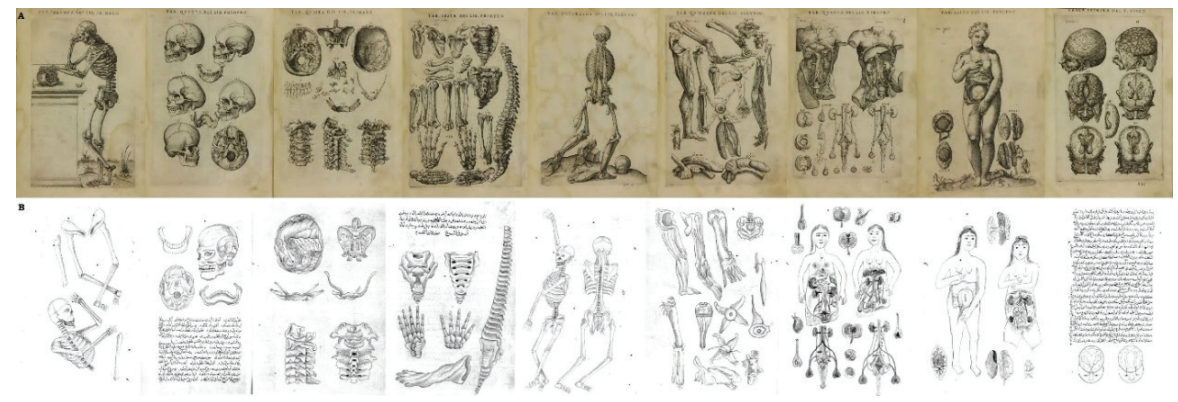

Figure 13. Spanish (A) edition (1556) of Juan Valverde's work entitled Historia de la composicion del cuerpo humano and Prof. Uzluk's personal copy of 'Itāqī's Tashrīh alAbdān (Courtesy of Department of History of Medicine, Faculty of Medicine, Ankara University, Ankara, Turkey) (B). 


\section{As conclusion \#1}

This limited study revealed that the information given by the works of Vesalius and Valverde has not influenced the explanations of 'Itāqī. 'Itāqī wrote his book according to the classical anatomical knowledge in the Islamic world of his era and he added Eastern- and Western-originated anatomical figures to his book to support/strengthen his statements. If it is accepted that 'Itāqi added figures to his work and the copy of Hüsrev Paşa, Nr. 464 is the closest copy to the original, then his source for the Western-originated figures in Tashrịh al-Abdān was Juan Valverde's Anatome corporis humani published in 1607.

\section{As conclusion \#2}

'Itāqi wrote his book according to the classical anatomical knowledge in the Islamic world of his era. Also, his work Tasrĭh al-Abdān originally contained no illustrations. However, later, scribes/copiers added Eastern- and Western-originated anatomical figures to the book to support/strengthen statements at different times. The four copies of Tashrīh al-Abdān without illustrations and variations between the illustrated copies are in favor of this idea, and Prof. Uzluk's copy of Tasrīh alAbdān directly supports it. It comprises many different illustrations in comparison to other illustrated copies.

\section{Acknowledgement}

Preparation for publication of this article is partly supported by the Turkish Neurosurgical Society. 


\section{BIBLIOGRAPHY}

'Abd al-Laṭ̂ি al-Baghdādī, Rihlat 'Abd al-Lațîf al-Baghdād̄̄ fì Mișr aw Kitāb al-Ifādat wa al-I tibār fì l-Umūr al-Mushahadat wa al-Hawādith al-Mu'āyanat bi-Ard Mișr, Al-Shaikh AA (ed), Țab`at al-Thāniya [The Second Edition], Hay'at alMișriyyat al-'Amat li-l-Kitāb 1998.

Abdel-Halim, Rabie E., "Experimental Medicine 1000 Years Ago", Urology Annals, III/2 (2011), pp. 55-61.

Abdülvehhâb bin Yûsuf ibn-i Ahmed el-Mârdânî, Kitâbu'l-Müntehab fîtt-Tıb (823/1420), İnceleme-Metin-Dizin-Sadeleştirme-Tıpkıbasım. Hazırlayan: Ali Haydar Bayat, Merkezefendi Geleneksel Tıp Derneği, İstanbul 2005.

Abū 'Alī Ibn Sīnā, Al-Q̄ānūn fì al-Ṭibb, Vol. II, al-Maṭba'at al-'Āmira, [Būlāq] $1294 /[1877]$.

Acıduman, Ahmet - İlgili, Önder, "Hekim Hayreddin'in "Hulâsatü't-Tıbb" Adlı Eserinde "Tibbi Deontoloji” ve "Nöroanatomi” ile İlgili Bölümler", Sinir Sistemi Cerrahisi Derg, II/1 (2009), pp. 45-51.

Adıvar, A. Adnan, Osmanl Türklerinde Ilim, 6. Basım, Remzi Kitabevi, İstanbul 2000.

Al-'Itāqī, The Treatise on Anatomy of Human Body and Interpretation of Philosophers, Esin Kahya (ed), National Hijra Council, Islamabad 1410/1990.

Avicenna (Abū 'Alī al-Husayn ibn 'Abd Allāh ibn Sīnā), The Canon of Medicine (alQānūn fì'l-tibb), Adapted by Laleh Bakhtiar from Translations of Volume I by O. Cameron Gruner and Mazar H. Shah Correlated with the Arabic by Jay R. Crook with Notes by O. Cameron Gruner, Series Editor Sayyed Hossein Nasr, Great Books of the Islamic World, Inc. 1999.

Bahşi, İlhan - Bahşi, Ayşe, "Teşrih-ül Ebdan ve Tercümânı Kıbale-i Feylesûfan”: the First Illustrated Anatomy Handwritten Textbook in Ottoman-Turkish Medicine", Surgical and Radiologic Anatomy, XLI/10 (2019), pp. 1135-1146.

Bayat, Ali Haydar, Tip Tarihi, 1. Baskı, Sade Matbaa, İzmir 2003.

Galen, On the Natural Faculties, with An English Translation by Arthur John Brock, William Heinemann, London; G.P. Putnam's Sons, New York 1916.

Galen, On the Usefulness of the Parts of the Body, De Usu Partium, Translated from the 
Greek with an Introduction and Commentary by Margaret Tallmadge May, I-II, Cornell University Press, Ithaca, New York 1968.

Haddad, Sami I. - Khairallah, Amin A., "A Forgotten Chapter in the History of the Circulation of the Blood", Annals of Surgery, CIV/1 (1936), pp. 1-8.

Huayrü'd-dīn ibn Elhạàc Bāyezīd bin 'Ömer Şāh, Kitābu Hulāsati't-Ṭıb, AÜTF Deontoloji AD Kütüphanesi, Nr. 15402/a, 1088/[1677-8].

Hekim Bereket, Tuhfe-i Mübārizī, Metin-Sözlük, Hazırlayan: Binnur Erdağı Doğuer, Türk Dil Kurumu Yayınları, Ankara 2013.

İhsanoğlu, Ekmeleddin (ed). Osmanh Tıbbi Bilimler Literatïrï Tarihi (History of the Literature of Medical Sciences During the Ottoman Period). 1. Cilt. Hazırlayanlar: Ekmeleddin İhsanoğlu, Ramazan Şeşen, M. Serdar Bekar, Gülcan Gündüz, Veysel Bulut, İslam Konferansı Teşkilatı, İslam Tarih, Sanat, Kültür Araştırma Merkezi (IRCICA), İstanbul 2008.

Kahya, Esin, "Şemseddin-i İtaki'nin Resimli Anatomi Kitabı", Araştrrma, VIII (1970), pp. 171-186.

Kâhya, Esin, "İbn Sînâ’nın Anatomisinin Osmanlı Hekimleri Üzerindeki Etkisi”, Bilim Tarihi, 15 (1993), pp. 3-6.

Kâhya, Esin, Şemseddîn-i İtâkînin Resimli Anatomi Kitabı, Atatürk Kültür, Dil ve Tarih Yüksek Kurumu, Atatürk Kültür Merkezi, Ankara 1996.

Kâhya, Esin, "One of the Samples of the Influences of Avicenna on the Ottoman Medicine, Shams al-Din Itaqi”, Belleten, LXIV/239 (2000), pp. 63-68.

Margócsy, Dániel - Somos, Márk - Joffe, Stephen N., "Vesalius' Fabrica: A Report On the Worldwide Census of the 1543 and 1555 Editions", Soc Hist Med, XXX (2017), pp. 201-223.

Meyerhof, Max, "Ibn An-Nafîs (XIII ${ }^{\text {th }}$ cent.) and His Theory of the Lesser Circulation", Isis, XXIII/ 1 (1935), pp. 100-120.

Nidhámí-i-'Arúdí-i-Samarqandí, The Chahár Maqála ("Four Discourses"), Translated into English by Edward G. Browne [Reprinted from the Journal of the Royal Asiatic Society, July and October, 1899], Luzac \& Co., London 1900.

O'Malley, Charles D. - Saunders, J. B. de C. M. (eds), Leonardo da Vinci on the Human Body: the Anatomical, Physiological, and Embryological Drawings of Leonardo da Vinci. Henry Schuman [1952]. 
Russell, Gül, "The owl and the pussy cat" the process of cultural transmission in anatomical illustration. Transfer of modern Science \& Technology to the Muslim World. Proceedings of the International Symposium on "Modern Sciences and the Muslim World". Science and Technology Transfer from the West to the Muslim World From the Renaissance to the Beginning of the XXth Century (Istanbul 2-4 September 1987), İhsanoğlu, Ekmeleddin (ed). The Research Centre for Islamic History, Art and Gulture (IRCICA), İstanbul 1992.

Sarton, George, Introduction to the History of Science, Volume II, from Rabbi Ben Ezra to Roger Bacon, in Two Parts, Part II, Reprinted, Published for the Carnegie Institution of Washington by the Williams and Wilkins Company, Baltimore 1962.

Saunders, J. B. deC. M - O’Malley, Charles D. (eds.), The Illustrations from the Works of Andreas Vesalius of Brussels, With Annotations and Translations, A Discussion of the Plates and Their Background, Authorship and Influence, and A Biographical Sketch of Vesalius by J. B. deC. M. Saunders and Charles D. O’Malley. Second Printing. Gleveland and New York: The World Publishing Company 1950.

Shah, Mazhar H., The General Principles of Avicenna's Canon of Medicine, Naveed Clinic, Karachi, Pakistan 1966.

Shams al-Dīn 'Itāqī. Tashrīh al-Abdān wa Tarjamān Qỉbāla Faylasūfān, Türkiye Yazma

Eserler Kurumu Başkanlı̆̆ı, İstanbul Süleymaniye Manuscript Library, Hüsrev Paşa Collection, Nr. 464.

Shams al-Dīn 'Itāqī, Tashrīh al-Abdān wa Tarjamān Qỉbāla Faylasūfān. İstanbul University, Turkish Manuscripts, TY 2662.

Shams al-Dīn 'Itāqī, Tashrịh al-Abdān wa Tarjamān Qỉbāla Faylasūfān. Ankara University, Institute of History of Medicine (B\&W Photo prints).

Shefer-Mossenshon, Miri, Ottoman Medicine: Healing and Medical Institutions, 15001700. State University of New York Press, Albany 2009.

Singer, Charles, "Galen's Elementary Course on Bones", Proceedings of the Royal Society of Medicine XLV/11 (1952), pp. 767-776.

Şehsüvaroğlu, Bedi N., "Bizde Anatomi Öğretimine Dair", İstanbul Üniversitesi Tıp Fakültesi Mecmuası XV/1 (1952), pp. 365-412. 
Terzioğlu, Arslan, "İbn Sīnā’nın Tabābeti ve Avrupa'ya Tesirleri”, İbn Sinnâ Doğımunun Bininci Yilı Armağanı. Aydın Sayılı (ed), T.C. Atatürk Kültür, Dil ve Tarih Yüksek Kurumu, Türk Tarih Kurumu Yayınları, Ankara 1984, pp. 41-66+13 figures.

Ullmann, Manfred, Islamic Medicine, Edinburgh University Press, Edinburgh 1978.

Uzluk, F. Nafiz, "İbni Sina Eşşeyhürreis", Büyük Türk Filozof ve Tıb Üstadı İbni Sina: Şahsiyeti ve Eserleri Hakknda Tetkikler, Türk Tarih Kurumu Yayınları, Muallim Ahmet Halit Kitap Evi, İstanbul 1937, pp:1-20.

[Ünver], A. Süheyl, "Üç Asırlık Resimli Bir Teşrih Kitabımız "Risalei Tarihi Ebdan” Şirvanlı Şemsettin (Itakî) 1622-1648”, Tedavi Notları, IX/7 (1934), pp. 189-193.

Vesalius, Andreas, De Humani corporis fabrica libri septem, Per Ioannem Oporinum. Basileae 1555.

Valuerde, Ioan de, Historia de la composcion del cuerpo humano, Impressa por Antonio Salamanca, y Antonio Lafrerij, En Roma 1556.

Valverde, Giouan, Anatomia del corpo humano \& da luy con molte figure di rame, et eruditi discorsi in luce mandata, In Roma Per Ant. Salamanca, et Antonio Lafrerj, 1559.

Valverdo, Ioanne, Anatome Corporis Humani, Nunc primum a Michaele Columbo latine reddita, et additis nouis aliquot tabulis exornata, Studio et industria Ivntarvm, Venetiis 1589.

Valverdo, Ioanne, Anatome Corporis Humani, Nunc primum a Michaele Colúbo latine reddita, et additis nouis aliquot tabulis exornata, Studio et industria Ivntarvm, Venetiis 1607.

Williams, Peter L. - Dyson, Mary (eds.), Gray's Anatomy, Thirty-Seventh Edition, ELBS edition first published 1992, Reprinted, ELBS with Churchill Livingstone, Edinburgh 1992. 


\section{APPENDIXS}

Table 1. Descriptions about the mandible.

\begin{tabular}{|c|c|}
\hline Galen & $\begin{array}{l}\text { "The bone of the lower jaw is not single, as one might think for, } \\
\text { when boiled, it, too, is separated at the point of the chin, so that it } \\
\text { is seen to be composite (Singer, 1952, p. 771)." }\end{array}$ \\
\hline Avicenna & $\begin{array}{l}\text { "The lower jaw is formed from the union of two bones which are } \\
\text { firmly joined at the chin (Avicenna, 1999, p. 62)." }\end{array}$ \\
\hline $\begin{array}{l}\text { 'Abd al-Lațîf } \\
\text { al-Baghdādī }\end{array}$ & $\begin{array}{l}\text { "However, based on our own observations, this organ [mandible] } \\
\text { is, first and foremost, one bone only without a joint or a symphysis. } \\
\text { Using various methods of testing, we examined it repeatedly, as } \\
\text { many times as willed by Allah, in many specimens whose number } \\
\text { exceeded two thousand skulls; but from all aspects we did not find } \\
\text { it except as a single bone. We also arranged the assistance of a } \\
\text { separated group who examined it [the mandible] in our presence } \\
\text { and then in our absence. They did not add anything to our } \\
\text { observations and reporting (Abdel-Halim, 2011, p. 59)." }\end{array}$ \\
\hline Vesalius & $\begin{array}{l}\text { "In many animals, maxillae [inferior] consists of two bones } \\
\text { connected by a union in the uppermost part of the chin. However, } \\
\text { for a human, it is made of a single bone (Vesalius, 1555, p. 54)." }\end{array}$ \\
\hline Valverde & $\begin{array}{l}\text { "All the beard, the teeth, the maxillaries together with the chin } \\
\text { are called maxilla inferior [lower jaw], that is made of two bones, } \\
\text { which join at the tip of the beard in children, through a line or joint } \\
\text { filled with cartilage, like the bone of the nape in adults, through } \\
\text { the joint called symphysis or union (Valverde, } 1559 \text {, f. 8r)." }\end{array}$ \\
\hline 'Itāqī & "The lower jaw consists of two bones (Al-'Itāqī, 1990, p. 44)." \\
\hline Gray's Anatomy & $\begin{array}{l}\text { "The mandible the largest, strongest and lowest bone in the face, } \\
\text { has a horizontally curved body, convex forwards, and two broad } \\
\text { rami, ascending posteriorly (Williams and Dyson (eds.), 1992, } \\
\text { p.367)." "At birth the two halves of the mandible are united by } \\
\text { a fibrous symphysis menti (Williams and Dyson (eds.), 1992, p. } \\
\text { 369)." "In the first to third postnatal years the two halves join at } \\
\text { their symphysis from below upwards; separation near the alveolar } \\
\text { margin may persist into second year (Williams and Dyson (eds.), } \\
\text { 1992, p. 369)." }\end{array}$ \\
\hline
\end{tabular}


Table 2. Information about the sacrum.

\begin{tabular}{|c|c|}
\hline Galen & $\begin{array}{l}\text { "The sacrum is composed of three parts, intrinsic vertebrae, as it } \\
\text { were, of its own, at the end of which lies a fourth, another bone, } \\
\text { called coccyx. When they are all cleaned by boiling, the structure } \\
\text { [of the sacrum] is seen to be same as that of the vertebrae (Singer, } \\
\text { 1952, p. 772)." }\end{array}$ \\
\hline Avicenna & "There are three vertebrae in the sacrum (Avicenna, 1999, p. 70)." \\
\hline Vesalius & $\begin{array}{l}\text { "Accordingly there are six bones above [the coccyx], which form } \\
\text { the sacrum. They are so constructed one after another that they } \\
\text { display a connection in the middle of the anterior place as the } \\
\text { bodies of the vertebrae would exhibit (Vesalius, 1555, p. 100)." }\end{array}$ \\
\hline Valverde & $\begin{array}{l}\text { "This bone [the sacrum] is hump behind, concave in front, and } \\
\text { usually has six vertebrae and sometimes five, so well joined that in } \\
\text { the inner part only a little sign of articulation is seen with difficulty } \\
\text { in aged people (Valverde, } 1559 \text {, p. 12r)." }\end{array}$ \\
\hline 'Itāqī & $\begin{array}{l}\text { "The Turkish meaning of sacrum is ['ajz] "roof bone" [çatı kemi- } \\
\text { gi] in Turkish. It is formed by three bones (Al-'Itāq1̄, 1990, p. 47)." }\end{array}$ \\
\hline $\begin{array}{l}\text { 'Abd al-Lațîf } \\
\text { al-Baghdādī }\end{array}$ & $\begin{array}{l}\text { "About the sacrum with the coccyx: Galen said that they consist } \\
\text { of six bones, [but] I found it as a single bone. I also considered in } \\
\text { all aspects and I found it as a single bone. Then I paid attention to } \\
\text { another corpse and I found it as six bones as Galen had said. I also } \\
\text { found it in other corpses as he said, except for two. On the con- } \\
\text { trary, I found it as a single bone in them and the joints were bound } \\
\text { in all. I am not confident as I am regarding the union of the lower } \\
\text { jaw ('Abd al-Latịf al-Baghdādī, 1998, p. 150)." }\end{array}$ \\
\hline Gray's Anatomy & $\begin{array}{l}\text { "The sacrum is a large, triangular fusion of five vertebrae and } \\
\text { forms the posterosuperior wall of the pelvic cavity, wedged be- } \\
\text { tween the two innominate bones (Williams and Dyson (eds.), 1992, } \\
\text { p. 324)." }\end{array}$ \\
\hline
\end{tabular}


Table 3. Explanations about the coccyx.

\begin{tabular}{|l|l|}
\hline Galen & $\begin{array}{l}\text { "At the end of the "broad bone" [sacrum] is the coccyx, which also } \\
\text { is of three parts. They are rather more cartilaginous than those } \\
\text { of the "broad bone", particularly that at the end (Singer, 1952, p. } \\
773) . "\end{array}$ \\
\hline Avicenna & $\begin{array}{l}\text { "The coccyx is made of three cartilaginous vertebrae which are } \\
\text { devoid of processes (Avicenna, 1999, p. 71)." }\end{array}$ \\
\hline Vesalius & $\begin{array}{l}\text { "There are also four little bones after the sacrum. From a cuckoo, } \\
\text { or from its beak shape, (...) just as though it is a single bone, it is } \\
\text { called kokkux by the Greeks as Latins do, in this manner, it will ex- } \\
\text { ist in history as ten bones turned into one (Vesalius, 1555, p. 100)." }\end{array}$ \\
\hline Valverde & $\begin{array}{l}\text { "The bone, which we generally call 'il Codione', is similar to that } \\
\text { of other animals; except that it does not appear in humans. And } \\
\text { it usually is made of four vertebrae \& sometimes three (Valverde, } \\
1559, \mathrm{f} .12 \mathrm{v}) . "\end{array}$ \\
\hline Gray's Anatomy & $\begin{array}{l}\text { "Coccyx ['uș'us] means 'kuyruk sokumu' in Turkish. It consists of } \\
\text { three soft bones which resemble cartilage (Al-'Itāqī, 1990, p. 48)." } \\
\text { "The coccyx, a small triangular bone, usually consists of four } \\
\text { three, the first being sometimes separate (Williams and Dyson } \\
\text { (eds.), 1992, p. 326)." }\end{array}$ \\
\hline
\end{tabular}


Table 4. Definitions about the metacarpus and the phalanges of the hand.

\begin{tabular}{|c|c|}
\hline Galen & $\begin{array}{l}\text { "The part between carpos and fingers is called the metacarpos. It } \\
\text { is synarthrōsed to the carpos but diarthrōsed to the first phalanges, } \\
\text { a name given to the finger-bones. Only the thumb has its first pha- } \\
\text { lanx diarthrōsed to the metacarpos at the side. Of the fingers, each } \\
\text { is formed of three bones, the end of each phalanx fitting into the } \\
\text { cavity placed at the beginning of the next. It seems reasonable to } \\
\text { say that the thumb too is made up of three bones and not to add } \\
\text { a first metacarpal to it, for it has a diarthrōsis at both ends, as with } \\
\text { the phalanges but not as with the metacarpals. Thus some would } \\
\text { reckon the metacarpals as four, and the bones of the five fingers } \\
\text { as fifteen. Alternatively some reckon fourteen phalanges and five } \\
\text { metacarpals (Singer, } 1952, \text { p. } 774) \text {." }\end{array}$ \\
\hline Avicenna & $\begin{array}{l}\text { "The four metacarpal bones articulate with the phalangeal bones } \\
\text { of the four fingers (Avicenna, 1999, p. 77)." "Each finger has three } \\
\text { phalanges (Avicenna, 1999, p. 77)." "The metacarpal bone of the } \\
\text { thumb has not been placed in line with the others, (...) (Avicenna, } \\
\text { 1999, p. 78)." }\end{array}$ \\
\hline Vesalius & $\begin{array}{l}\text { "(...) I will call it [metakarpion/palm] postbrachial. According to } \\
\text { Galen it is made of four bones and made of five according to Cel- } \\
\text { sus and Aristotle. Doubtless, they add the bone of the thumb ar- } \\
\text { ticulated to the fifth brachial bone to the postbrachial, and Galen, } \\
\text { to speak the truth, adds it to the bones of digits (Vesalius, 1555, p. } \\
\text { 146)." "We mentioned in the previous chapter that every finger of } \\
\text { the hand is made of three bones (Vesalius, 1555, p. 149)." }\end{array}$ \\
\hline Valverde & $\begin{array}{l}\text { "The comb or palm of the hand (...) We could say that it consists } \\
\text { of five bones; because the first joint of the pollex is very similar to } \\
\text { the first joint of the other fingers as well; \& to count, like all others } \\
\text { count, I always will say that they are four (Valverde, 1559, f.18v)." } \\
\text { "Each finger of the hand consists of three bones (Valverde, 1559, } \\
\text { f. 19r)." }\end{array}$ \\
\hline 'Itāqī & $\begin{array}{l}\text { "The bones on the back of the palm are called 'metacarpal bones' } \\
\text { [mushț which means comb. They are four bones ('Itāqīi, Hüsrev } \\
\text { Paşa Collection 464, f. 35r)]. Their carpal ends are thin, (...) (Al- } \\
\text { 'Itāqī, 1990, p. 51)." "Each finger has three bones. They are called } \\
\text { phalanges [sulāmiyyāt] (Al-'Itāqī, 1990, p. 51)." }\end{array}$ \\
\hline Gray's Anatomy & $\begin{array}{l}\text { "The metacarpus (Singh 1959) consists of five metacarpal bones, } \\
\text { conventionally numbered in lateromedial order (Williams and Dys- } \\
\text { on (eds), 1992, p. 418)." "There are } 14 \text { phalanges, three in each } \\
\text { finger, two in the pollex (Williams and Dyson (eds.), 1992, p. 420)." }\end{array}$ \\
\hline
\end{tabular}


Table 5. Descriptions about the metatarsus and the phalanges of the foot.

\begin{tabular}{|l|l|}
\hline Galen & $\begin{array}{l}\text { "Here begins what is called the [metatarsos] pedion. It is formed } \\
\text { of five bones, next to which lie the toes, all of three phalanges as } \\
\text { with the fingers, except the big toe, which alone has but two (Singer, } \\
\text { 1952, p. 775)." }\end{array}$ \\
\hline Avicenna & $\begin{array}{l}\text { "There are five metatarsal bones (Avicenna, 1999, p. 82)." "All toes, } \\
\text { except the big toe, have three phalanges. The big toe has only two } \\
\text { (Avicenna, 1999, p. 82)." }\end{array}$ \\
\hline Vesalius & $\begin{array}{l}\text { "Accordingly pedion corresponds to the postbrachial of the hand. } \\
\text { Truly it is formed of five bones, not four as postbrachial (Vesalius, } \\
1555, \text { p. 180)." "Then follows the toes after the bones of the foot. } \\
\text { Each toe is composed of three bones, which was constructed the } \\
\text { similitude to every finger in the hand, except the pollex [hallux], } \\
\text { which is alone composed of two bones (Vesalius, 1555, p. 181)." }\end{array}$ \\
\hline Valverde & $\begin{array}{l}\text { "This comb of the foot [metatarsus] is similar to that of the hand, } \\
\text { except that it has five bones;" "Toes of the foot (...) each one is made } \\
\text { of three bones, like those in the hand, except the pollex [hallux], } \\
\text { which does not have more than two (Valverde, 1559, f. 25r)." }\end{array}$ \\
\hline Gray's Anatomy & $\begin{array}{l}\text { "The metatarsal bones are the feet bones. They are five in number, } \\
\text { (Itāqi 1990, p. 53)." "The toes consist of thirteen [fourteen] bones } \\
\text { and each toe has three phalanges, but big toes have two phalanges } \\
\text { each (Al-Itāqī, 1990, p. 53)." } \\
\text { phalanges in general resemble those in the hand; there are two in } \\
\text { the hallux, and three in each of the other toes (Williams and Dyson } \\
\text { (eds.), 1992, p. 455)." }\end{array}$ \\
\hline
\end{tabular}


Table 6. Remarks about the rete mirabile.

\begin{tabular}{|c|c|}
\hline Galen & $\begin{array}{l}\text { "The plexus called retiform [rete mirabile] by anatomists, is the } \\
\text { most wonderful of the bodies located in this region. It encircles the } \\
\text { gland [the hypophysis] itself and extends far to the rear; for nearly } \\
\text { the whole base of the encephalon has this plexus lying beneath it } \\
\text { (Galen, 1968, pp. 430-431)."; "For when they [arteries] have passed } \\
\text { beyond the cranium, in the space between it and the thick meninx, } \\
\text { they are first divided into many very small, slender arteries, and then } \\
\text { they are interwoven and pass through one another, some toward } \\
\text { the front of the head, some toward the back, and others to the left } \\
\text { and right, giving the other, opposite impression, namely, that they } \\
\text { have forgotten the route to the encephalon (Galen, 1968, p. 431)." }\end{array}$ \\
\hline Avicenna & $\begin{array}{l}\text { "This arterial network spreads out between the bone and its thick } \\
\text { fibrous membrane [dura mater] (Shah, 1966, p. 115)." }\end{array}$ \\
\hline Vesalius & $\begin{array}{l}\text { "There is no reticular plexus under the brain, as Galen described it } \\
\text { to be exist (Vesalius, 1555, p. 796)." } \\
\text { "In the first of these figures we have sketched the reticular plexus as } \\
\text { it ought to be to agree with Galen's description in his book "On the } \\
\text { Use of Parts" (Vesalius, 1950, p. 198)." }\end{array}$ \\
\hline Valverde & $\begin{array}{l}\text { "In this figure, the rete mirabile is represented, so-called by Galen, } \\
\text { which I never saw either in humans or in other animals (Valverde, } \\
1559, \text { f.117r)." "I will not mention from the marvelous network [the } \\
\text { rete mirabile], because it is not seen in humans (Valverde, 1559, f. } \\
\text { 131v)." }\end{array}$ \\
\hline 'Itāqī & $\begin{array}{l}\text { "This membrane also covers that network (chorioid phlexus } \\
\text { [choroid plexus]) [shabaka dimāgh] which is situated between the } \\
\text { occipital bone [qā'ide kemigi] and the dura mater [kalın perde/ } \\
\text { umm jāfiyya (Al-'Itāqīi, 1990, p. 89)." }\end{array}$ \\
\hline
\end{tabular}


Table 7. Information about the uterus.

\begin{tabular}{|c|c|}
\hline Galen & $\begin{array}{l}\text { "Now though the neck is single, Nature has not made just one } \\
\text { hollow in the uteri. In the pig and certain other animals that must } \\
\text { bear many fetuses [at one time], she has made very many sinuses, } \\
\text { but in man and animals resembling man, just as the whole body is } \\
\text { double with right and left sides, so too there is one sinus placed in } \\
\text { the right part of the uterus and another in the left (Galen 1968, p. } \\
625) . " \text { " "Certainly this is a wonderful work of hers, but I am sure } \\
\text { that you will think it beyond all marvels for the number of sinuses } \\
\text { to be made the same as the number of teats (Galen, 1968, p. 625)." }\end{array}$ \\
\hline Avicenna & $\begin{array}{l}\text { "There are two cavities in the human uterus and in others [animals], } \\
\text { as many as their number of teats (Ibn Sīnā, 1877, p. 556)." }\end{array}$ \\
\hline Vesalius & $\begin{array}{l}\text { "Even though the fundus of the female uterus is bestowed with a } \\
\text { single sinus, Galen assigned two sinuses to it in his account of the } \\
\text { uterus, especially when he described the uterus and also when he } \\
\text { tried to weave his reasons in De usu partium (Vesalius, 1555, p. 666). }\end{array}$ \\
\hline Valverde & $\begin{array}{l}\text { "Outside this line, there is no other thing worthy inside the matrix; } \\
\text { nor are there many chambers of cells in some fools have found, and } \\
\text { many more have believed (Valverde, } 1559, \text { p. 90r)." }\end{array}$ \\
\hline 'Itāqī & $\begin{array}{l}\text { "There are two cavities in the human uterus. In other animals, the } \\
\text { number of the cavities is the same as the number of the breasts. } \\
\text { For instance, the cavities of the uterus in dogs are eight in number } \\
\text { (Al-Itiāqī, 1990, p. 116)" }\end{array}$ \\
\hline Gray's Anatomy & $\begin{array}{l}\text { "The uterine cavity is relatively small, partly due to its thick wall. } \\
\text { The cavity of the body is a mere transverse slit in sagittal section, the } \\
\text { anterior and posterior walls being almost in contact (Williams and } \\
\text { Dyson (eds.), 1992, p. 1441)." }\end{array}$ \\
\hline
\end{tabular}


Table 8. Descriptions about how blood passes from the right ventricle to the left ventricle.

\begin{tabular}{|c|c|}
\hline Galen & $\begin{array}{l}\text { "Similarly, also, in the heart itself, the thinnest portion of the blood is drawn from the } \\
\text { right ventricle into the left, owing to there being perforations in the septum between } \\
\text { them: these can be seen for a great part [of their length]; they are like a kind of } \\
\text { fossae [pits] with wide mouths, and they get constantly narrower; it is not possible, } \\
\text { however, actually to observe their extreme terminations, owing both to the smallness } \\
\text { of these and to the fact that when the animal is dead all the parts are chilled and } \\
\text { shrunken (Galen, 1916, p. 321)." }\end{array}$ \\
\hline $\begin{array}{l}\text { Ibn al- } \\
\text { Nafís }\end{array}$ & $\begin{array}{l}\text { "When the blood has been refined in this ventricle, it must reach the left ventricle } \\
\text { where the pneuma }(a r-r \bar{u} h) \text { is formed. But between these two ventricles there is no } \\
\text { passage because the substance of the heart is here compact (musmat). In it there is } \\
\text { neither a visible passage, as some suppose, nor any invisible passage which would } \\
\text { serve to carry the blood through, as Galen thought, because the pores (masamm) of } \\
\text { the heart are closely placed here and its substance is firm. Thus this blood, it has } \\
\text { been refined, must certainly reach the lungs by the arterial vein, so that it can spread } \\
\text { out in their substance and mix with the air, so that its finest constituents can be } \\
\text { clarified, and so that it can then reach the venous artery, and from there the left } \\
\text { ventricle (Ullmann, 1978, pp. 68-69)." }\end{array}$ \\
\hline Vesalius & $\begin{array}{l}\text { "The surface of each ventricle is very uneven and is sown with many pits, so to speak, } \\
\text { deeply sunk into its fleshy substance.... Though these pits are sometimes conspicuous, } \\
\text { none of them, so far as can be perceived by the senses, penetrates through the septum } \\
\text { of the ventricles from the right ventricle into the left. I have found no openings - not } \\
\text { even most obscure ones - making the septum of the ventricles pervious, even though } \\
\text { they are described by professors of dissection, because these men consider it most } \\
\text { convincing that blood is taken over from the right ventricle into the left. Hence .... I } \\
\text { find myself in no little doubt about the office of this part of the heart (Galen, 1968, } \\
\text { n. 87, pp. 323-324)." }\end{array}$ \\
\hline 'Itāqī & $\begin{array}{l}\text { "We have already mentioned three ventricles of the heart. All anatomists give the } \\
\text { same information. But Ibn an-Nafis in his Commentary on the Anatomical Section } \\
\text { of the Qanon claimed that this was wrong, and said that the heart had two ventricles; } \\
\text { one of them was the right ventricle in which the blood coming from the liver was } \\
\text { cooked, and then sent into the left ventricle where blood was cooked to a certain } \\
\text { degree and refined; blood was then sent to the lungs. In the lungs, it mixed with the } \\
\text { air and nourished the lungs. The same blood which mixed with air came to the heart. } \\
\text { The heart distributed the spirit to the whole body. Ibn an-Nafis said that there was } \\
\text { no cavity between the right and left ventricles. He also said that they were separated } \\
\text { by a fleshy septum which resembled a sponge. The blood passed through this spongy } \\
\text { flesh from the right ventricle to the left. The heart continuously contracts and dilates. } \\
\text { Its nourishment is blood which is found in itself. For, the heart is heavy and its blood } \\
\text { is heavy; its nourishment should resemble itself. Ibn an-Nafis said that the blood } \\
\text { which came from the liver was changed into spirit and distributed into the body by } \\
\text { the heart. God knows best (Al-Itāqi 1990, p. 105)." }\end{array}$ \\
\hline
\end{tabular}


